\title{
Strategic personnel management: context of retirement age reform in Russia
}

\author{
Tatiana Stuken \\ Dostoevsky Omsk State University, Omsk, Russia \\ Olga Korzhova \\ Dostoevsky Omsk State University, Omsk, Russia
}

\begin{abstract}
Since January 2019, retirement age in the Russian Federation will be gradually raised. Over the next ten years, the retirement age will be raised by five years to 60 years for women and 65 years for men. The Russian labor market is characterized by a fairly high level of ageism, manifested in the reluctance of employers to hire people older than 40-45 years, to train and promote workers of pre-retirement age. The decrease in the number of young generations and the increase in the proportion of older people actualize the tasks of working with aged personnel. Given these circumstances, organizations will respond to external challenges, adapting their personnel policies to new realities. The aim of this work is to identify the willingness of organizations to employ older workers in terms of pension reform in Russia, and determine how to change HR practices in these conditions. The paper consists of two parts. In the first part, authors analyze the trends associated with the increasing share of older generations on the Russian labor market and the qualitative characteristics of this group of workers. The information base is the Russian Federal State Statistics Service microdata (labor force survey) and the Russian Longitudinal Monitoring Survey. Based on this, there are made conclusions about the segments of employment of pre-retirement age workers (50 years for women and 55 years for men) in the labor market and their competitiveness. The second part of the paper presents results of expert survey of heads of HR-activities of 38 organizations of a large Russian city on the need and opportunities to expand the use of the labor of pre-retirement age workers, including the transformation of personnel management technologies to new realities:

- possibility and conditions of using attractive for older workers working hours;

- willingness of employers to participate in the training of personnel of pre-retirement age and conditions of investment in their human capital;

- changes in the practices of recruitment, adaptation and release of personnel, taking into account changes in the Russian legislation.

The main results of the study: organizations operating in highly competitive markets and facing a shortage of personnel, demonstrate a willingness to expand the use of older workers' labor and adapt the existing HR practices to them.However, most employers are not yet ready to change their personnel practices and adapt them to the increase in the older labor force in the labor market. To support older workers in the labor market there is required the elaboration of state programs for the adaptation of employees of pre-retirement age in the labor market.
\end{abstract}

\section{Keywords}

Personnel management, ageism, older workers. 


\section{Introduction}

The Russian Federation is one of the countries with an aging population. In 2018 the share of the population in the retirement age was equal to $25 \%$ of the total population. According to the demographic prediction, this share will rise above $30 \%$ by 2035 . It is widely known that the aging population reduces the flow of new labor force in the economy and reduces the total labor force as a whole. It also creates an additional burden on the working population concerning the support of the non-working population.

There are three global solutions to the problem of aging population, allowing minimizing its negative impact on the economy and the labor market:

- immigration of working-age population from the least economically developed countries;

- automation of production processes that reduce the need for labor;

- raising the age of participation in the labor force.

The analysis of the Russian situation shows the limited possibilities of using these methods.

First, the country has a zero average annual migration balance of the working-age population.

Secondly, the level of technology development and economic sanctions lead to the fact that Russia has a significant lag behind the leading economies in the automation of production processes (Work in Transition, 2018). In addition, the widespread availability of low-skilled and low-paid workers makes capital substitution uneconomical.

Thus, the main solution to the problem of population ageing in Russia is to increase the participation of the older population in the labor force. It should be noted that the retirement age in Russia is one of the lowest. Until the beginning of 2019, it was 55 years for women and 60 years for men.

Since 2019, the country has launched a pension reform, consisting of a gradual increase in the retirement age by 2023 to 60 years for women and 65 years for men. It is expected that this measure will solve the main problems. An increase in the length of the older population's participation in the labor force will compensate for a decrease in the inflow of young people into the labor force. Raising the retirement age will make it possible to achieve the necessary balancing of incomes and expenditures of the Pension Fund of Russia, as well as to increase the size of pensions.

However, the solution of these problems ultimately depends on the behavior of economic agents, the configuration of benefits and costs. The increase in the length of stay of the older population in the labor market is the result of both the supply of labor and the demand for labor.

On the one hand, at present, it is legitimate to raise the question of raising the age of participation in the labor force due to increase of the actual level of labor force participation of people who have reached retirement age, increase of life expectancy and improvement of the population health, reduction in the number of jobs with difficult working conditions in industrial production and an increase in the number of jobs in the service sector, rising educational level of an older population and relatively high level of development of their competencies (Klepikova \& Kolosnitsina, 2017).

On the other hand, according to the theory of human capital, the knowledge and skills of the employee depreciate with age, so the wages of workers begin to decline. This reduction is higher the higher the need for the physical effort of the employee and the use of competencies related to the flexibility and adaptability of the employee (Gordo \& Skirbekk, 2013; Gimpelson, 2018). Moreover, the ongoing automation and digitalization leads to an increased demand for computer skills. This may increase the unemployment rate, especially among workers of pre-retirement age (Nica, Manole \& Stan, 2018; Sorells, 2018; Nica, 2018). This problem is also considered in a gender perspective (Kral, Janoskova, Podhorska, Pera \& Neguriță, 2019).

Specialists engaged in the study of the labor market, note the existence of not only theoretical dependencies, but also a number of negative stereotypes associated with the use of older workers' labor (Hedge, Borman \& Lammlein, 2006; Conen, Van Dalen \& Henkens, 2012). In relation to the Russian market, there is also a fairly wide prevalence of age discrimination ageism. After 40 years, Russian workers face problems in finding work, older workers' jobs are limited to sectors of the economy with low wages, older workers' earnings are, all other things being equal, lower than those of younger workers (Klepikova \& Kolosnitsina, 2017; Gimpelson, 2018). An attempt to solve this problem was the introduction by the state in 2018 of criminal 
punishment for unjustified refusal to hire or unjustified dismissal of a citizen five years or less before retirement age, the consequences of which are ambiguously assessed by experts.

These problems indicate the need to analyze the characteristics of the demand for older workers not only through macroeconomic assessments, but also microeconomic studies. Many of them face the challenges of hiring workers in the labor market. However, this does not mean that they will respond to the signal from the state and become more active in the use of older workers' labor.

Literature analysis showed that in many countries employers have already begun to change their personnel management practices for older workers. For example, there is a study devoted to the changes in Dutch employers' behavior regarding the recruitment and retention of older workers in 2000-2009. The authors conclude that the position of older workers has improved between 2000 and 2008. During the recession, recruitment of older workers declined substantially, while efforts to retain older workers are in both absolute and relative terms higher than in 2000. With respect to organizational policies, the authors conclude that throughout the period under observation these policies are dominated by measures that "spare" older workers. (Conen, Henkens \& Schippers, 2011). In particular, in order to cope with an increased proportion of older workers, organizations develop old-age adaptation policies (Ivanova, 2018; Lössbroek, Lancee, Van der Lippe \& Schippers, 2019). But it should be noted that in many cases the human resources management practices have changed to a very limited extent. Organizations are still not engaging in practices tailored to mature employees because it is not a priority for organizations (Armstrong-Stassen, 2008).

The object of the study is the practice of working with personnel in the conditions of the pension reform carried out in Russia. Calculations show that if the labor force participation rate of this population group increases, women over 55 and men over 60 will make up $14-15 \%$ of the total labor force, compared to $8.8 \%$ at present. The majority of older workers are sufficiently skilled. The predominant areas of employment are education, health, manufacturing, trade. The most effective, according to experts, the work of older workers can be in the workplaces of highly skilled workers and specialists. At the same time, the effectiveness of their work in the workplaces of managers, especially linear, is estimated as quite low.

According to the results of the expert survey, the majority of HR managers is sympathetic to raising the retirement age, but are not ready to expand the use of older workers in their organizations. Strengthening the position of older workers in the labor market requires additional efforts on the part of the state.

\section{Research methods}

This study consists of two parts. The first part assesses the participation of the older population in the labor force and the qualitative characteristics of this group of the labor force. The article shows an increase in the participation of the older population in the labor force, taking into account the pension reform and changes in the age structure of the population. Information base of the study is representative for the Russian Federation microdata population survey on employment Federal state statistics service (2017) and HSE University (2017).

The second part of the study is aimed at assessing the reaction of employers to changes in the retirement age. The study is based on an expert survey of employers of the Omsk - city, which according to its economic, demographic and social characteristics occupies middle position among the major Russian cities with population 500 thousand people and more. This gives reason to believe that the situation with the use of older workers in Omsk is typical for large Russian cities, whose labor markets are developing most actively.

There were interviewed experts representing 38 organizations of large and medium-sized businesses operating in Omsk, on the use of labor of older workers (women of 50 years and older, men of 55 years and older). The selection of organizations took into account their belonging to the types of economic activity, where the work of older workers is the most common (production, transport and storage, education, health, public administration, trade).There were used the following criteria for selection of experts: holding the position of the head of human resources departments of organizations, or their deputy, or employees who individually perform the functions of personnel manager in organizations; the presence of work experience in the field of management for at least five years. The expert survey included the following blocks: characteristics of older workers; efficiency of 
older workers in the context of jobs; opportunities and conditions for expanding the use of older workers; adaptation of personnel management practices for older workers.

The results were processed using descriptive statistics methods.

\section{Older workers on the Russian labor market}

The older Russian population has a fairly high level of labor force participation. The high labor force participation rates at the pre-retirement age (50-54 for women and 55-59 for men) are almost halved in the first five years after retirement and are around $10 \%$ thereafter. At the same time, older women have a slightly higher labor force participation rate than men (table 1).

Table 1 Participation in the labor force of the Russian population in older age, $\%$

\begin{tabular}{l|c|c|c}
\hline Group & employed & unemployed & inactive \\
\hline Men & 67,5 & 3,8 & 28,7 \\
\hline $\begin{array}{l}\text { including: early- } \\
\text { retirement age }\end{array}$ & 75,5 & 3,8 & 20,7 \\
\hline $\begin{array}{l}\text { in the first five years } \\
\text { after retirement age }\end{array}$ & 37,8 & 1,4 & 60,8 \\
\hline $\begin{array}{l}\text { in 5ears since } \\
\text { retirement }\end{array}$ & 8,3 & 0,3 & 91,5 \\
\hline $\begin{array}{l}\text { Women } \\
\text { Including: early- } \\
\text { retirement age }\end{array}$ & 52,8 & 2,8 & 44,3 \\
\hline $\begin{array}{l}\text { in the first five years } \\
\text { after retirement age }\end{array}$ & 83,0 & 3,1 & 13,9 \\
\hline $\begin{array}{l}\text { in 5ears since } \\
\text { retirement }\end{array}$ & 45,6 & 1,6 & 52,9 \\
\hline \multicolumn{2}{|c}{ Source: The authors }
\end{tabular}

A five-year increase in the retirement age will lead to an increase in the labor force participation of the part of the population that is now in the "first five years after retirement age" group. Calculations show that if the labor force participation rate of this population group increases, women aged 55 and over and men aged 60 and over will make up $14-15 \%$ of the total labor force compared to $8.8 \%$ at present (authors' calculations). Such a significant increase in the labor supply of this population group requires a more careful study of its characteristics.

According to the authors' calculations, workers in this age group have a fairly high level of education. According to the classification currently used in Russia, $24.4 \%$ of employees in this group have higher education, and $44.4 \%$ have secondary vocational education. More than $90 \%$ of the employed are concentrated in a relatively small list of economic activities (Fig. 1).

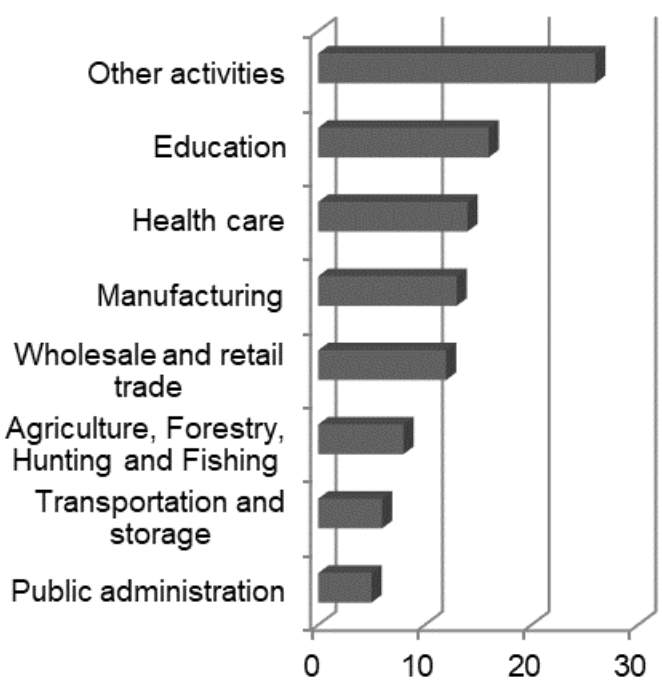

Figure 1 The work characteristics of older workers (Percentage of the total experts surveyed) Source: The authors

Most often, employees of the "new" preretirement and retirement age work as skilled workers $(20.4 \%)$ and specialists $(38.2 \%)$. About $15 \%$ of them are employed in trade, $13.9 \%$ are unskilled workers, and $8.3 \%$ are managers of different levels.

\section{Personnel management in the context of pension reform}

The expected growth in the labor supply among older workers should obviously have an impact on the labor market and on the company's personnel policy. Let's stop on the results of the experts' survey.

The results confirmed the presence of certain stereotypes regarding the characteristics of older workers (Fig. 2).

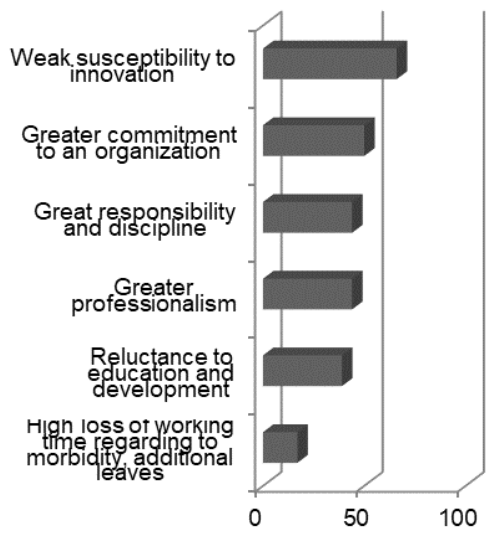

Figure 2 The work characteristics of older workers (percentage of the total experts surveyed) Source: The authors 
The Fig. 2 shows that older workers are prescribed both positive (commitment to the organization, professionalism, responsibility and discipline) and negative (especially often - a weak susceptibility to innovation, unpreparedness for learning and development) qualities. At the same time, state-owned companies or companies with state participation in the authorized capital more often point out the greater commitment to an organization and high professionalism, and private companies mention a weak susceptibility to innovation and loss of working time. These differences are probably to some extent the result of differences in the market position of companies. Relatively low public sector wages determine the demand for commitment and loyalty, and a highly competitive private business environment determines the demand for susceptibility to innovation.

The majority of respondents confirm the existence of ageism problem on the Russian labor market.

In response to the question whether experts are aware of cases of denial of employment to candidates because of their age, $92 \%$ of respondents reported that they know about such cases. More than half $(58 \%)$ of experts believe that such cases will occur more often as the pension reform progresses. Overall, $84.2 \%$ of experts fear that the situation of older persons in the labor market will worsen (answering these questions, the experts assessed the situation in the labor market as a whole, and not in their companies).

Speaking about the efficiency of older workers in their organizations, the experts identified two niches - highly skilled workers and specialists. In their opinion, high professionalism of these workers can provide the maximum result at these workplaces. The efficiency of this group of workers in the workplaces of managers, especially linear, is estimated as low.

Increasing the number of older workers as the retirement age rises will require employers to adapt to the new situation. With the exception of some labor market niches where the prevalence of older workers is traditionally high due to high skill requirements and / or low wages (e.g. education, health, industry, transport), the rest of the companies will have to adapt to the new situation. Thus, it is known that older workers often have a need for flexible working hours. The extension of the period of employment actualizes the issues of training and development of this group of workers. Objectively worse health of older workers increases the demand for corporate social programs related to health maintenance and medical care.

Our research has shown that employers, who are generally sympathetic to the need to raise the retirement age, tend to believe that it is their organizations that will be least affected by the pension reform. The majority of respondents (more than $80 \%$ ) are ready to expand the use of older workers only if external conditions change (a significant increase in demand for products, the provision of financial benefits from the state, the introduction of additional requirements for the use of older people by the state). Only about a quarter of the experts reported having or developing personnel management technologies adapted to the use of older workers. The main changes employers associate with the development (use) of part-time programs, flexible working time regimes, the transfer of older workers to jobs with a lower load, allowing keeping the employee and using his labor potential (table 2).

Table 2 Willingness to use personnel management practices adapted for older persons, \% of respondents

\begin{tabular}{l|c|c}
\hline Personnel management practices & \multicolumn{2}{|c}{ Answers } \\
\cline { 2 - 3 } & Exists & $\begin{array}{c}\text { Doesn't exist, but it } \\
\text { is planned }\end{array}$ \\
\hline Part-time employment & 10,5 & 5,3 \\
\hline Flexible working hours & 10,5 & 13,2 \\
\hline Preparing for retirement & 15,8 & 10,5 \\
\hline Additional days off & 0,0 & 7,9 \\
\hline $\begin{array}{l}\text { Workplaces creation for older } \\
\text { workers }\end{array}$ & 0,0 & 5,3 \\
\hline
\end{tabular}

Source: The authors

Some employers also declare partial adjustment of practices of selection, adaptation of personnel and development of personnel. At the same time, there is a certain dependence of the mention of these practices with the conditions in which the organization operates. More often than others, relatively small non-governmental organizations with the number of employees up to 100 people point to the use and development of practices of working with older workers.

One of the main problems of employment of older people is considered to be outdated knowledge and skills. Most often there is a need to develop soft skills, computer skills, skills in engineering and technology $(37-45 \%$ of respondents).

However, most employers are not prepared to bear the costs of training of this group of employees. More than a half of the respondents believe that maintaining the competitiveness of 
this group of workers is solely the task of the state. Another $24 \%$ believe that this task should be solved by the state together with other stakeholders. Employers are ready to engage in this work either with incentives or with the use of additional administrative resources by the state. A significant number of employers are ready to use non-market methods of solving the problem by creating jobs for this group of workers by the state, similar to the practices of subsidizing jobs for disabled people, which are widely used in the country (Fig. 3).

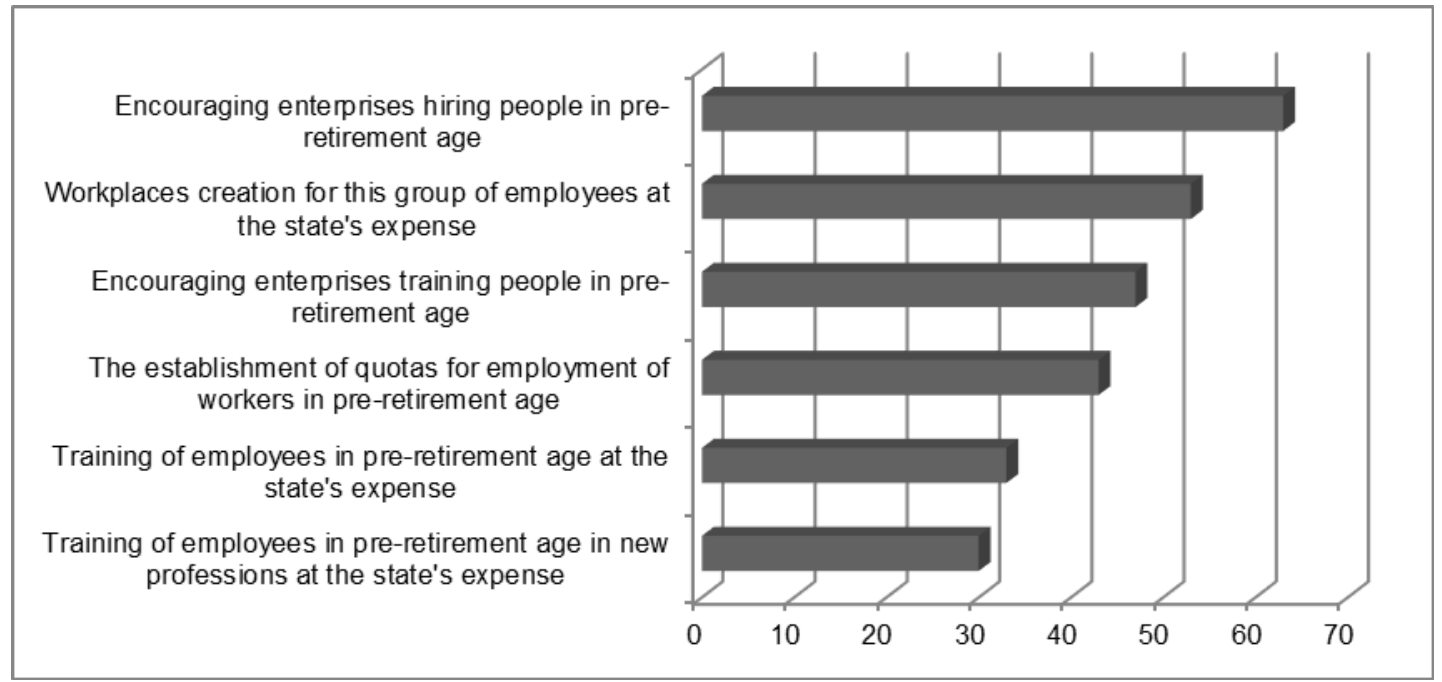

Figure 3 Distribution of responses to the question "What do you think, what kind of effort from the government are necessary to take to not cause negative consequence for older workers because of the increasing the retirement age?" (percent of the total experts surveyed) Source: The authors

The introduction of criminal penalties for unjustified refusal to hire or for unjustified dismissal by the majority of experts (more than $80 \%$ ) is not perceived as an effective measure. This is largely due to the lack of elaboration of the rules and the ambiguity of the interpretation of unjustified refusal or dismissal. On the other hand, the application of this rule will lead to the fact that unreasonable refusals and dismissals will be applied in advance, before the pre-retirement age established in the legislation.

\section{Conclusion}

Thus, faced with the problems of shortage of labor of the necessary quality in the conditions of pension reform, firms operating in highly competitive markets are beginning to think about changing the practices of work with personnel and strategic decisions regarding work with older personnel. For such employers adaptation of personnel practices to the work with employees of senior age becomes actual. This includes the use of part-time programs, the introduction of flexible working hours, and the transfer of older workers to jobs with less workload.
At the same time, most employers are not yet ready to change the practices of working with personnel and adapt them to the increase in the share of older workforce in the labor market. They are either waiting for additional impacts from the state, or rely on increasing the intensity of employment of younger workers.

Both conclusions are consistent with the data of foreign studies. We believe that in the Russian Federation, changing the practices of working with staff will be harder because of the widespread ageism, reducing the prevalence of which requires serious and targeted measures on the part of the state.

Special attention should be paid to the problem of personnel training. Raising the retirement age will require investment in training older workers in new skills. And this need will be the higher, the more complex the work which is performed by the employee. Theoretically, an increase in the retirement age increases the return on investment in human capital, but only $5 \%$ of experts reported an increase in training practices for older workers. The concerns of others are related to the already mentioned low susceptibility of this group to innovation and unpreparedness for learning. 
Thus, employers are willing to employ older workers in highly skilled jobs of workers and specialists, but are not willing to invest in their development, hoping for state assistance.sm

\section{References}

Armstrong-Stassen, M. (2008). Human resource practices for mature workers - and why aren't employers using them? Asia Pacific Journal of Human Resources, 46 (3), 334-52.

https://doi.org/10.1177/1038411108091755

Conen, W. S., Henkens, K. \& Schippers, J. (2011). Are employers changing their behavior toward older workers? An analysis of employers' surveys 20002009. Journal of Aging and Social Policy, 23 (2), 14158. https://doi.org/10.1080/08959420.2011.551612

Conen W. S., Van Dalen H. P., Henkens K. (2012) Ageing and employers' perceptions of labour costs and productivity. International Journal of Manpower, 33 (6), 629-647. https://doi.org/10.1108/01437721211261796

Federal state statistics service. (2017). Labor force survey. [database]. Retrieved January 18, 2019, from: http://old.gks.ru/wps/wcm/connect/rosstat_main/rosstat/ ru/statistics/publications/catalog/doc_1140097038766

Gimpelson, V. E. (2018). Age, productivity, wages. Retrieved January 19, 2019, from: https://wp.hse.ru/data/2018/12/10/1145005536/WP3_20 18_07 .pdf

Gordo L., Skirbekk V. (2013). Skill demand and the comparative advantage of age: Jobs tasks and earnings from the 1980s to the 2000s in Germany. Labour Economics. 22, 61-69. https://doi.org/10.1016/j.labeco.2012.09.003

Hedge J.W., Borman W.C., Lammlein S. E. (2006) The Ageing Workforce: Realities, Myths and Implications for Organizations. Washington, DC: American Psychological Association. https://doi.org/10.1037/11325-000

HSE University (2017). The Russia Longitudinal Monitoring Survey - Higher School of Economics (RLMS-HSE). [database]. Retrieved January 18, 2019, from: https://www.hse.ru/en/rlms/
Ivanova, M.A. (2018) Pension system and labor activity: International experience. Issues of Economics. 10, 5375.

https://doi.org/10.32609/0042-8736-2018-10-53-75

Klepikova E.A., \&Kolosnitsina M.G. (2017). Ageism in the Russian labor market: wage discrimination, Russian Management Journal. 15 (1), 69-88. https://doi.org/10.21638/11701/spbu18.2017.104

Kral, P., Janoskova, K., Podhorska, I., Pera, A. \& Neguriță, O. (2019). The automatability of male and female jobs: Technological unemployment, skill shift, and precarious work. Journal of Research in Gender Studies, 9(1), 146152.

https://doi.org/10.22381/JRGS9120197

Lössbroek, J., Lancee, B., Van Der Lippe, T., \& Schippers, J. (2019). Understanding old-age adaptation policies in Europe: The influence of profit, principles and pressures. Ageing and Society, 39 (5), 924-950. https://doi.org/10.1017/S0144686X17001295

Nica, E. (2018). Will Robots Take the Jobs of Human Workers? Disruptive Technologies that May Bring About Jobless Growth and Enduring Mass Unemployment, Psychosociological Issues in Human Resource Management, 6 (2): 56-61. https://doi.org/10.22381/PIHRM6220184

Nica, E., Manole, C. \& Stan, C. (2018). A Laborless Society? How Highly Automated Environments and Breakthroughs in Artificial Intelligence Bring About Innovative Kinds of Skills and Employment Disruptions, Altering the Nature of Business Process and Affecting the Path of Economic Growth, Journal of SelfGovernance and Management Economics, 6 (4), 2530.

https://doi.org/10.22381/JSME6420184

Sorells, B. (2018). Will Robotization Really Cause Technological Unemployment? The Rate and Extent of Potential Job Displacement Caused by Workplace Automation, Psychosociological Issues in Human Resource Management, 6 (2), 68-73. https://doi.org/10.22381/PIHRM6220186

Work in Transition: Transition report 2018-19 (2018). European Bank for Reconstruction and Development. Retrieved January 19, 2019, from: https://www.ebrd.com/transition-report

\section{$\bowtie$ Correspondence}

\section{Tatiana Stuken}

Dostoevsky Omsk State University, Ploshad' Litskevicha,1, 644053, Omsk, Russia

E-mail: stukentiu@omsu.ru 